\title{
Research on the Application of Reversing Classroom in College English Teaching in Private Colleges and Universities
}

\author{
Wenjuan Zhao ${ }^{1, \text { a }}$ \\ ${ }^{1}$ Xi'an International University, Shaanxi, Xi'an, China, 710077 \\ aemail,
}

\begin{abstract}
Keywords: Inverted Classroom; English Teaching; Private Colleges and Universities; Applied Research
\end{abstract}

\begin{abstract}
With the development of society and economy, the domestic education industry is also constantly optimizing the upgrade, after the implementation of the new curriculum reform, the domestic education industry has undergone tremendous changes, the people's attention to education has reached an unprecedented height. How to reform the teaching mode, how to liberate the classroom teaching from the traditional model, the improvement of the English level has become a problem that many private college teachers need to think about. In the new environment, the current situation tells us that a single rely on knowledge to achieve the level of teaching to improve the model has been gradually eliminated. Therefore, in this important stage of transformation, the reform of English classroom teaching model is imminent. How to use the educational philosophy of the new environment to carry out the construction of scientific and efficient teaching mode, improve the teaching level, reduce the pressure of students, improve teaching efficiency, is committed to each other or is committed to the cause of English education comrades must face and solve problem. The emergence of the flip mode is an important turning point in the transformation of teaching mode is a reform of the traditional teaching model, a kind of innovation and subversion.
\end{abstract}

\section{Introduction}

Traditional teaching mode under the teaching of the form of most of the script, the teacher to teach the teaching does not understand for the students do not care. Teachers, so the preaching of doubts also, but many teachers are still not completely converted to teachers as teachers. Most of them are still on the surface, in fact, in addition to the output of knowledge, but also need to guide students to explore, learn to share knowledge. Teachers as a bridge of knowledge transfer, change the traditional teaching philosophy, so that students learn to form a positive and optimistic attitude. So that students learn theoretical knowledge at the same time, to develop a good habit of independent study. We need to stimulate students in all possible circumstances of the subjective initiative, the passive to the initiative, the difficulties for the simple, to help students learn science.

\section{The Connotation of the Flipping Classroom}

In the existing university teaching, the traditional teaching mode in the rote, spoon, sea tactics and so on the teaching model through the practice test, is not suitable for the existing English teaching environment, the training of students cannot achieve the desired level, students' English proficiency is limited. In order to change the lack of teaching in this traditional model, so that students get better development and progress, improve the overall quality of students, strengthen the students of geography, we need to change the traditional, model innovation and thinking changes, To flip the construction of the classroom, so that English learning more interesting.

Reduce the dependence of students on textbooks, so that students through the development of the times in line with the English learning, learning content and knowledge points for editing production, in the form of teaching video to students, so that students through a variety of channels for English learning, nor Subject to geographical and time constraints, anytime, anywhere can be English learning. After the initial teaching video to watch, and then the classroom learning, teachers and students in the video content to discuss and deepen the expansion, we will jump out of the 
traditional teaching model of the new way called turn the classroom [1]

\section{The Characteristics of Flipping Classroom}

The Use of the Teaching Video Is More Refined. Television and traditional blackboard teaching mode is different, it is more intuitive feeling. Traditional teaching materials and teacher lectures have greater limitations, but the production of English teaching video, whether from the auditory, visual or other senses, have a more intense impact, can make people quickly into the state, and Put place in the transposition of thinking, with more powerful than the traditional model of appeal and persuasion [2]. In addition, the teaching video is more extensive and informative than the traditional written course, and the content is more extensive and comprehensive in the same time period. In general, the video of this type is shorter in time. The transmission of knowledge points are after repeated refining the results, so more professional and refined, so that students learn more easily grasp. In addition, the production of such teaching video generally does not appear other interference factors, will make students more focused, not affected by interference factors. And the video with the traditional model there is a greater feature is to repeat the play, for the fuzzy point can be observed many times, so that learning more flexible and more efficient.

Break the Original Teaching Process and Construct New Models. In the traditional teaching process, the first step is to explain the teacher's textbook knowledge, some professional knowledge points on-site direct teaching to complete the transmission of knowledge, followed by the second step is the students will be the classroom knowledge and content to absorb and digestive understanding, which is currently the general process of teaching English, this process for students is more restrictive, the students on the acceptance of knowledge is more unexpected, after-school digestion may also be a problem, for the focus of the omission will often happens. And flip the classroom will be the traditional process to break, and reconstruction [3]. So that students through the teaching of video knowledge of the relevant point of learning, will be difficult, focus on mastering the knowledge system in advance to build, and then through the original knowledge system based on classroom learning, this with a certain learning base of the great teaching To improve the efficiency of learning, so that students in the classroom for the difficulty of the key to grasp, re-digestion and absorption, for the fuzzy point of the key memory, so that students learn more targeted and focused, greatly improving the efficiency of student learning. The construction of this new system for students to learn handy for the improvement of English has an important role.

\section{The Role of Flipping Classroom in College English Teaching in Private Colleges and Universities}

Greatly Improve Students' Interest in Learning. Turn the construction of the classroom, whether it is in the teaching model of innovation, or in space and space on the open, than the traditional model has a huge change, this change can greatly attract the attention of students, turn the classroom for the interest of the guide Sex is very great, only to fully stimulate the enthusiasm of students to learn interest in order to give full play to the students' subjective initiative, the passive to take the initiative, with less. Only when the students are interested, they will focus on learning, only the classroom vivid, in order to allow students to experience the joy of learning. English teaching knowledge points, wide coverage, practical and strong, teachers in a limited time to a large number of knowledge points to be transmitted, it is easy to cause the classroom boring, so that students get weariness. And especially in the moment, students for paper teaching visual fatigue make traditional English teaching more difficult. And the construction of the classroom can be more humane, close to the way students to the knowledge point of the narrative, to reduce the difficulty of teaching, improve the coverage of knowledge, make up for the limitations of traditional teaching, improve student interest.

Change the Traditional Teaching Model and Teaching Model Innovation. At present, in English teaching, teaching methods of traditional single, or follow the traditional way of scripting, boring, poor flexibility. But the English language for the quality of the classroom requirements are 
very high, in the listening exercises and the English scene to restore, etc., so that video teaching is particularly important, it can have a clearer visual experience and hearing effects. English video has a more intuitive feel, the traditional teaching materials and teachers of lectures have great limitations, but the flip of the classroom building, whether from the listening angle, visual or other senses, have a more intense impact. It will allow students to more three-dimensional to observe, to think, so that students can quickly enter the state, but also to the professional English professional special can be closer to reality, with more than the traditional model of more appealing and persuasive.

\section{The Application Strategy of Flipping Classroom in College English Teaching in Private Colleges and Universities}

Use Mobile Phones, Computers and Other Electronic Equipment to Build the Learning Platform. Mobile phone as a daily necessity of communication, both carry out daily communication, but also as a learning resource sharing carrier. To the mobile phone as the carrier, so that classes and classes, students and teachers and students to establish a learning group, to discuss some of the teaching problems, teaching resources to share some of the relevant bridge building examples, bridge-related information sharing. So that from the media services in the bridge project learning, so that learning method more diversified, more modern means of learning. You can also use the computer, the establishment of a public account, so that students through the video push to learn. Or to set up e-mail, the classroom will need the teaching video and teaching materials to pass. Let the students become electronic equipment services in learning, a variety of learning platform to build [4].

Use Inquiry-Based Learning Model and Training Students English Comprehensive Ability. Flip the classroom to enable students to have more autonomy, inspired students to self-study and study the ability to develop students' integrated English ability to provide an opportunity. In the long course of teaching practice found that many students in reading and writing and other aspects of strong ability, and listening and speaking these two aspects of the ability is weaker. In the flip classroom, teachers can set the relevant questions in the pre-class study materials, ask students to listen to the answer to find the answer, the real students to play the initiative, and thus improve the effect of watching the video; in improving the ability to express this, teachers can Students are required to use English as much as possible in class discussions. Students can express their ideas through various forms of expression, such as role play and impromptu speech.

Make Efforts to Create an Active Classroom Atmosphere and Pay Attention to Fill Gaps. In the construction of the flip classroom, teachers must first change the traditional teaching itself is the main idea of teaching, it is necessary to pay attention to the student's main position, but also play their own guiding role, let the students dare to ask questions, willing to ask questions; for students Questions, teachers to be patient Q \& A; if you find pre-class video or audio missing in the knowledge points, teachers should be promptly added; In addition, the teacher also on the overall performance of students, that students in the learning process of the lack of To guide them to better study.

\section{Conclusion}

Breaking the traditional English classroom teaching stereotyped boring, teaching means of innovation and use new teaching model is the new era of English teaching the inevitable demands. Especially for the English teachers of private colleges, the traditional mode of change, the use of new ways and means, combined with modern science and technology, to establish a more in line with the development of new English teaching model, the introduction of the classroom into English teaching, the development of the times, but also an important means to improve classroom efficiency. For students, it is also an important measure to improve learning interest, stimulate ideological activity and improve learning efficiency. The author summarizes some of the work experience in the work, hoping to provide the basis for the theory of English teaching. Due to the 
limitations of cognitive, but also hope that many scholars can conduct analysis.

\section{References}

[1] Li Xiaoyan, Wang Zhixiong.Application of "flip classroom" model in college English teaching in the context of informationization [J]. English Plaza, 2015, 12: 93-94.

[2] Gao Qirong, Xie Li, Long Shuangyan, Nie Yuanyuan, Zhang Jin. "Internet +" era of the new class - to flip the classroom in college vocational college English teaching application [J]. English square, 2016,09: 93-95.

[3] Zeng Su-fang, Zhu Chao-chao.Study on Promoting the Teaching of Public Basic Courses in Colleges by Using Tilting Classroom Teaching - Taking "College English Teaching" as an Example [J]. China Agricultural Education, 2016,05: 56-59.

(School of Economics and Management, Southwest Jiaotong University, Xi'an 710049, China); The Feasibility Analysis of the Application of Inverted Classroom in College English Teaching in Private Colleges [J]. Rural Economy and Science \& Technology, 2016, 24: 278.

[5] Wang Xiaodong, Zhang Chenjing Aberdeen. Application of "flip classroom" in university teaching - Taking English course of educational technology as an example[J]. Modern Educational Technology, 2013,08: 11-16. 